\title{
Determination of Physiological, Biochemical and Molecular Effects of Zinc Stress on the Growth of Sunflower Seedlings (Helianthus annuus L.)
}

\author{
Ekrem Bolukbas $1^{1 *}$, Aysenur Bolukbas1 ${ }^{2}$, Sumer Aras $^{3}$ \\ ${ }^{1}$ Department of Biology, Faculty of Science \& Arts, Amasya University, Amasya,Turkey \\ ${ }^{2}$ Department of Biology, Faculty of Science, Karatekin University, Cankiri, Turkey \\ ${ }^{3}$ Department of Biology, Faculty of Science, Ankara University, AnkaraTurkey
}

\begin{abstract}
Heavy metal contamination is an important environmental problem all over the world. High concentrations of heavy metals cause permanent damage stocells and tissues. In this study, the toxic effects of zincheavy metal in sunflower plant in population and molecular parameters were investigated. The effects of zincheavymetalon sunflower seedlings were determined using the changes in population parameters; rootlength, dry weight, and total solubleprotein content. Total protein content of sunflower plants was determined in a relationship in the opposite direction increasing the amount of metal concentrations. Genotoxic effects of heavymetal of zinc on sunflower plants were revealed by using changes in genomic template stability (GTS). According to analyses, serious changes in genomic template stability were detected and these results were compared with the growth, dry weight and total soluble protein content of the seedlings grown at various zinc concentrations. Also, it was seen that the genomic template stability significantly affected the primary root length, root dry weight and root total soluble protein content. Positive correlations were observed between physiological, biochemical and molecular parameters in sunflower seedlings under zinc stress.In conclusion, a comparison between physiological, biochemical and molecular parameters shows that zinc is a genotoxic agent for sunflower plants.
\end{abstract}

Keywords-Genotoxic effect; Heavy metal; Sunflower; Zinc stress.

\section{INTRODUCTION}

Sunflower (Helianthus annuus L.) has economic importance in terms of agriculture in the worldwide. The high level of its fatty acid (69\%) easily explains the importance of the sunflower plant (Lentz et al., 2008; Blackmana, 2011). Environmental pollution took place because of the necessity to create areas for urbanized living and then it has increased since then with the improvement of industry. Especially after 1950s, the rapid growth of the population has caused our natural resources to be polluted even more and the ecosystem has got serious damages (Yarsan et al., 2000).If the environmental changes affect a plant's normal growth and development in a negative way, the reaction or the general situation of the plant is called stress. According to Levitt, stress factors have two different groups; biotic and abiotic. According to this classification, abiotic factors are the most dangerous ones which include heavy metals and threaten the ecological balance (Levitt, 1972). Heavy metals which can be heavily accumulated in soil, water and air is now a common environmental concern to take precautions immediately and it is equally dangerous for every living organism from plants to human (Yarsan et al., 2000). Several industrial activities, urban waste, exhaust gases, mining activities, some volcanic activities, disinfection and fertilisation held in agriculture, heavy use of pesticides are some of the examples of heavy metal pollution. This pollution also causes decrease in the quality of agricultural products (KirbagandMunzuroglu, 2006). Heavy metals also give damage to most of the functional biomolecules including membrane lipids and this results in increase of some reactive oxygen types such as (ROS), hydroxyl radicals, $(\mathrm{OH} \cdot)$ or hydrogen peroxide, $\left(\mathrm{H}_{2} \mathrm{O}_{2}\right)$ superoxide anion, $\left(\mathrm{O}_{2}^{-}\right)$which cause oxidative stress (BurzynskiandKlobus, 2004;Koc et al., 2012). It is also known that heavy metals cause genotoxicity in living things. This situation occurs as a results of treating organisms with some chemical, biological and physical agents that leads to damages in their genetic materials (Steinkellner et al., 1998;Savva, 2000;Hall, 2002). Zinc is a microelement which should be taken in very less amounts by plants, animals and humans. In the deficiency of zinc, RNA levels and the cell's ribosome content decrease and this situation leads to a decrease in the protein formation mechanism. Besides, in deficiency of zinc in the plants, indexes of indol-3-acedic acid (IAA), abscisic acid and tryptophan amino acid levels also decreases. This situation gives damages to the normal growth of the plants and affects the herbal production in a serious way.The toxic effect of $\mathrm{Zn}^{2+}$ cause damages to the 
cell division and it especially gives damages to the cell nucleus of meristematic stem cell (Koc et al., 2012). At the same time, $\mathrm{Zn}^{2+}$ stress results in clorosis, which is defined as a damage in the activity of chloroplast and shrinking of the plant's size. It also affects the productivity and decreases the amount of chlorophyll and resolubleproteins, the length of the root, the weight and the amount of the seed (KhuranaandChatterjee 2001;BekiarogluandKarataglis, 2002; Koc et al., 2012). In this current study, it was aimed to determine the effect of zinc heavy metal on sunflower seedlings by the use of physiological parameters such as stem/root elongation and RAPD analysis for possible genotoxicity, which is one of the PCR-based molecular indicators.

\section{MATERIAL AND METHODS} Germination method, measurement of total soluble protein and length of root

Sunflower seeds' surfaces were sterilized with $70 \%$ alcohol and 30\% sodium hypochlorite solution and washed three-four times with distilled water. For germinating and growing of sunflower seeds, seedling trays were filled with sterilized perlite and seeds were planted in each cell of seedling tray. The seedling trays were divided into eight groups in total, including control and seven different concentrations of zinc solution. Control group of the tray was treated with only $15 \mathrm{~mL}$ of distilled water. The other groups of the trays were treated with $15 \mathrm{ml}$ of $20,40,80,160,320,640$ and $1280 \mathrm{mg} \mathrm{L}^{-1}$ concentrations of $\mathrm{ZnSO}_{4} \cdot 6 \mathrm{H}_{2} \mathrm{O}$ zinc solutions for each, respectively. These treatments were replicated twice. All these procedures were performed for 21 days. After 21 days of treatment, each plant samples' root and stem length belonging to different groups of sunflower seedlings were measured and the harvested plants were frozen in liquid nitrogen and stored at $-20^{\circ} \mathrm{C}$ until DNA extraction. Total soluble protein of the sunflower seedlings were measured according to the Bradford method (Bradford, 1976).

\section{DNA extraction and RAPD procedures}

The piece $(200 \mathrm{mg})$ of roots obtained from the seedlings after 21 days of growth procedure was grounded with liquid nitrogen in eppendorf tubes, and total genomic DNA isolation was performed with the DNA isolation protocol of Lefort (Lefort,1998).The quantity and quality of DNA samples were determined by Nanodrop Spectrophotometer (ND-1000 Thermo Scientific) and also confirmed by gel electrophoresis which contains $1.5 \%$ agarose and $0.05 \mu \mathrm{ml}^{-1}$ ethidium bromide. After then, the DNA samples with suitable purity and concentration levels were selected to be used in RAPD procedure. RAPD-PCR study was performed with total $25 \mu$ of standard reaction volume for each sample. Optimum amplification conditions were obtained with 200ng genomic DNA, $1 \times$ reaction buffer, $2.5 \mathrm{mM} \mathrm{MgCl}_{2}, 20 \mu \mathrm{M}$ dNTPs, $0.2 \mathrm{mM}$ primer, and $0,5 \mathrm{U}$ Taq DNA polymerase (Promega). 14 of 20 RAPD primers used in this study revealed polymorphic bands that are different from the control group of sunflower. Fourteen RAPD primers [5' $\rightarrow 3^{\prime} ; \quad$ (OPA-03) AGTCAGCCAC; (OPA-08) GTGACGTAGG; (OPB-07) GGTGACGCAG; (OPC-01) TTCGAGCCAG; (OPC-02) GTGAGGCGTC; (OPC-04) CCGCATCTAC; (OPC-05) TGGACCGGTG; (OPC-06) GAACGGACTC; (OPC-07) GTCCCGACGA; (OPC-08) TGGACCGGTG; (OPC-09) CTCACCGTCC; (OPC-10) TGTCTGGGTG; (OPC-11) AAAGCTGCGG; (OPF-05) CCGAATTCCC ] were used for RAPD-PCR reactions. The thermal cycling conditions included an initial denaturation step of $95^{\circ} \mathrm{C}$ for $5 \mathrm{~min}$, followed by 35 cycles of $94^{\circ} \mathrm{C}$ for $90 \mathrm{~s}$ (denaturation), $36^{\circ} \mathrm{C}$ for $60 \mathrm{~s}$ (annealing), and $72^{\circ} \mathrm{C}$ for 120 s (extension) followed by a final extension period of $72^{\circ} \mathrm{C}$ for $5 \mathrm{~min}$. Negative control PCR, not including any DNA template was run for each samples for testing any other kinds of DNA contaminations. All PCR reactions were carried out in duplicate. PCR reaction products and DNA ladder (DNA ladder plus, Promega 100bp) were subjected to an electrophoretic separation process for $2-2,5 \mathrm{~h}$, under $5 \mathrm{~V}$ $\mathrm{cm}^{-1}$ current in $1.5 \%$ agarose gel containing $0.05 \mu \mathrm{lml}^{-1}$ ethidium bromide. The gels were displayed with UV imaging system and photographed with using GyneSnap Software (Synoptics Co). After then, the gel photographs were analyzed for identifying the RAPD profiles.

\section{Calculating the genomic template stability (GTS)}

After analysis of the RAPD profiles, genomic template stability (\%) was calculated with the following formula: $G T S=\left(1-a n^{-1}\right) \times 100$, where letter of a; refers to polymorphic band number of each sample, which was treated with the different zinc solutions and the letter of $\mathrm{n}$; refers to the total band number in the control. The appearance or disappearance of bands in the treated samples' RAPD profiles in comparison to the control RAPD profiles were identified as polymorphism.

\section{Statistical analysis}

The SPSS (statistical package software v. 17.0 Multilanguage for Windows) was used to analyze the changes in root length, dry weight and total soluble protein content. Data were tested by performing the paired sample t-test.

\section{RESULTS AND DISCUSSION}

The effect of zinc on physiological and biochemical parameters

One of the effects of toxins is to prevent the root and body growth. The accumulation of heavy metals in plant causes 
negative effects on roots, stems and germination of seeds; when it is exposed to the increasing concentrations of heavy metals (Zenginand Munzuroglu, 2004). Similarly, as expected in sunflower plants, the findings of this study on the length of sunflower seedlings' roots and stems are similar with the related literature. In this study, for 21 days, when the samples which were exposed to heavy metal stress with different $\mathrm{Zn}^{2+}$ concentrations are evaluated, the improvement of plants' roots and stems length have suggested that there is a clear decrease in parallel with the increasing concentration of $\mathrm{Zn}^{2+}$, as expected. However, it was observed that there was an increase in root and stem lengths and improvement of plants which were exposed to $20 \mathrm{mg} \mathrm{L}^{-1}$ and $40 \mathrm{mg} \mathrm{L}^{-1}$ of zinc stress. It was found that, in the plant samples which were exposed to $20 \mathrm{mg} \mathrm{L}^{-1}$ and $40 \mathrm{mg} \mathrm{L}^{-1}$ of zinc stress, the root and stem lengths were more than the control group. This was also an expected finding. The reason for this is that in some levels, zinc can be used as a micronutrient (Koc et al., 2012). When it was used with $80 \mathrm{mg} \mathrm{L}^{-1}$ or more concentration, the root and stem lengths were decreased. In other words, as the concentration of zinc increased, the root and stem lengths of the sunflower seedlings decreased. Decreases between $11-88 \%$ in the root lengths of the sunflower seedlings were observed compared to the control plants. Besides, when it was used with $80 \mathrm{mg} \mathrm{L}^{-1}$ or more, it was observed that in the roots, there were tarnishing and it increased gradually. It is indicated that tarnishing takes place when the suberin level increases and this situation limits the water intake of the plant (BarceloandPoschenrieder, 1990) (Figure 1).

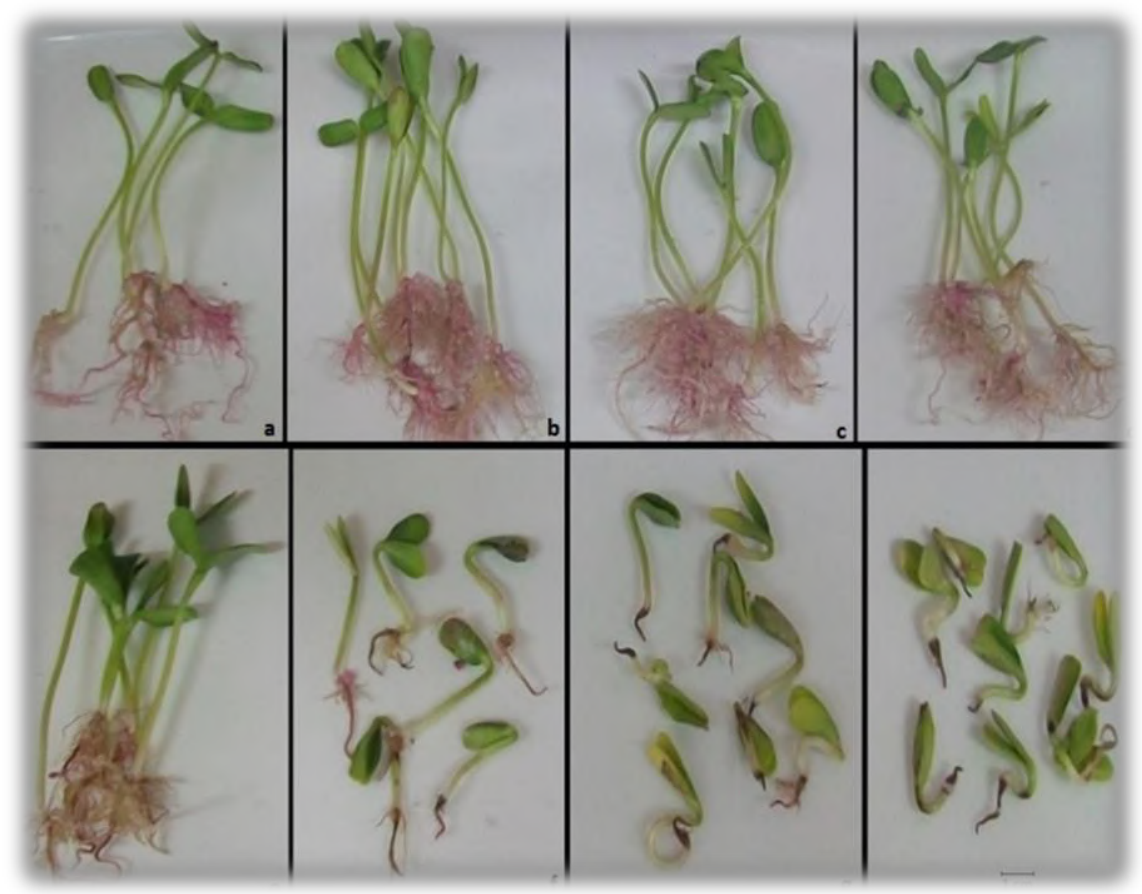

Fig.1: The views of sunflower seedlings a; control group sunflower samples, $b$; sunflower samples of exposed to $20 \mathrm{mg} L^{-1}$ Zn stress, c; $40 \mathrm{mg} \mathrm{L}^{-1}, d$; $80 \mathrm{mg} \mathrm{L}^{-1}$, e; $160 \mathrm{mg} \mathrm{L}^{-1}, \mathrm{f} ; 320 \mathrm{mg} \mathrm{L}^{-1}$, g; $640 \mathrm{mg} \mathrm{L}^{-1}, \mathrm{~h}$; $1280 \mathrm{mg} \mathrm{L}^{-1}$

Nevertheless, statistically significant differences for the effects of zinc stress on the root development was observed above $80 \mathrm{mg} \mathrm{L}^{-1}(P<0.05)$. A gradual decrease was determined in sunflower seedlings after $80 \mathrm{mg} \mathrm{L}^{-1}$ depending on the increasing concentrations of zinc $(P<$ 0.01).With $320 \mathrm{mg} \mathrm{L}^{-1}$ concentration, zinc had similar negative effects on the root length of the sunflower seedlings $(P<0.001)$. However, above $160 \mathrm{mg} \mathrm{L}^{-1}$, zinc had more negative effects on the root and stem length ofsunflower seedlings compared to control group (Table 1).

Table.1: Sunflower seedlings were exposed to various zinc (Zn) concentrations $\left(\mathrm{mg} \mathrm{L}^{-1}\right)$. Changes in the root length (cm seedling $\left.{ }^{-1}\right)$, dry weight ( $g$ seedling $\left.{ }^{-1}\right)$, total protein content $\left(\mathrm{mg} \mathrm{ml}^{-1}\right)$ and GTS rate (\%).

\begin{tabular}{lcccccccc}
\hline & C & Zn 20 & Zn 40 & Zn 80 & Zn 160 & Zn 320 & Zn 640 & Zn 1280 \\
\hline Root length & 8.5 & 9.5 & $9.0^{*}$ & $7.5^{*}$ & $4.0^{* *}$ & $2.3^{* *}$ & $1.5^{* * *}$ & $1.0^{* * *}$ \\
Dry weight & 0.0072 & 0.0073 & 0.0072 & $0.0066^{*}$ & $0.0058^{* *}$ & $0.0046^{* *}$ & $0.0040^{* *}$ & $0.0028^{* * *}$ \\
$\begin{array}{l}\text { Total protein } \\
\text { content }\end{array}$ & 0.0405 & 0.0440 & 0.0410 & $0.0328^{* *}$ & $0.0308^{* *}$ & $0.0249^{* * *}$ & $0.0211^{* * *}$ & $0.0187^{* * *}$ \\
\hline
\end{tabular}




GTS rate $\quad 100 \quad 92.85$

$n=14$ for each group. $* P<0.05, * * P<0.01, * * * P<0.001$

The toxic effect of some heavy metals $(\mathrm{Pb}, \mathrm{Cu}, \mathrm{Ni}, \mathrm{Zn}$, $\mathrm{Mn}$ and $\mathrm{Cd}$ ) give damages to the cell structure and physiological activity; it especially results in clorosis, which is defined with the damage in the activity of chloroplast and decreases of the plant's size. It also affects the productivity and decreases the amount of chlorophyll and resoluble proteins. As a result, it leads to a negative effect on the production of dry weight (Khuranaand Chatterjee, 2001;BekiarogluandKarataglis, 2002; Koc et al., 2012). Compared to the control group, the exposure to zinc stress with $80 \mathrm{mg} \mathrm{L}^{-1}$ and more, resulted in a decrease in sunflower seedlings' dry weight. The negative effect was observed even more in sunflower seedlings' dry weight with the losses between $8-60 \%$ when they were exposed to $80 \mathrm{mg} \mathrm{L}^{-1}$ and more concentrations, respectively.Also, there was a consistent relationship between the dry weight and the length of the heavy metal treated root. $R^{2}$ value of the dry weight-root length for increasing concentrations of zinc treatment were found to be 0.9892 (Figure 2).

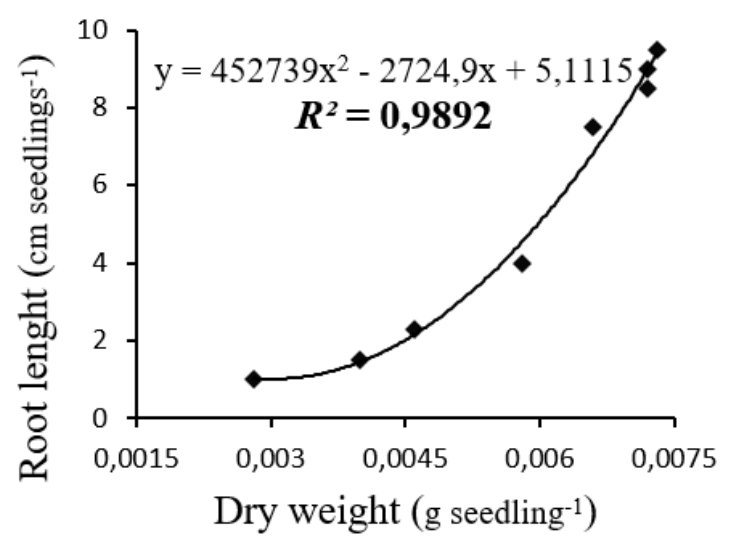

Fig.2: Influence of root dry weight to primary root length and $R^{2}$ value

Similar to the decreases in the dry weight, the length of root and total soluble protein contents of all the sunflower seedlings effected due to the increase in heavy metal concentration. Similarly, it was indicated that the increase in the concentrations of lead, cadmium and copper causes a decrease in the total protein content of sunflower cucumber and artichoke respectively (Kastori et al., 1992; Soydam et al., 2012; Batir et al., 2016). In this study, when the soluble protein indexes were evaluated in sunflower plants after the applications of zinc solution with different concentrations, the level was found as $0.0405 \mathrm{mg} \mathrm{L}^{-1}$ in control group. On the other hand, in $20 \mathrm{mg} \mathrm{L}^{-1}$, the total protein level was found to be $0.0440 \mathrm{mgL}^{-1}$ and in $1280 \mathrm{mg} \mathrm{L}^{-1}$, it was found to be $0.0187 \mathrm{mgL}^{-1}$. There was an observed increase in $20 \mathrm{mg} \mathrm{L}^{-}$
${ }^{1}$ and $40 \mathrm{mg} \mathrm{L}^{-1}$. When it was increased to $80 \mathrm{mg} \mathrm{L}^{-1}$ and more concentrations, the protein content was observed to decrease gradually. At the same time, positive correlations were observed between the root total soluble protein content and the root dry weight as well as between the root total soluble protein content and primary root length for zinc treatments in sunflower seedlings. It was seen that root total soluble protein content significantly affected the root dry weight $\left(R^{2}=0.9828\right)$. In addition, primary root length was significantly affected by the root total soluble protein content in sunflower seedlings exposed to zinc stress $\left(R^{2}=0.9365\right)$ (Figure 3).
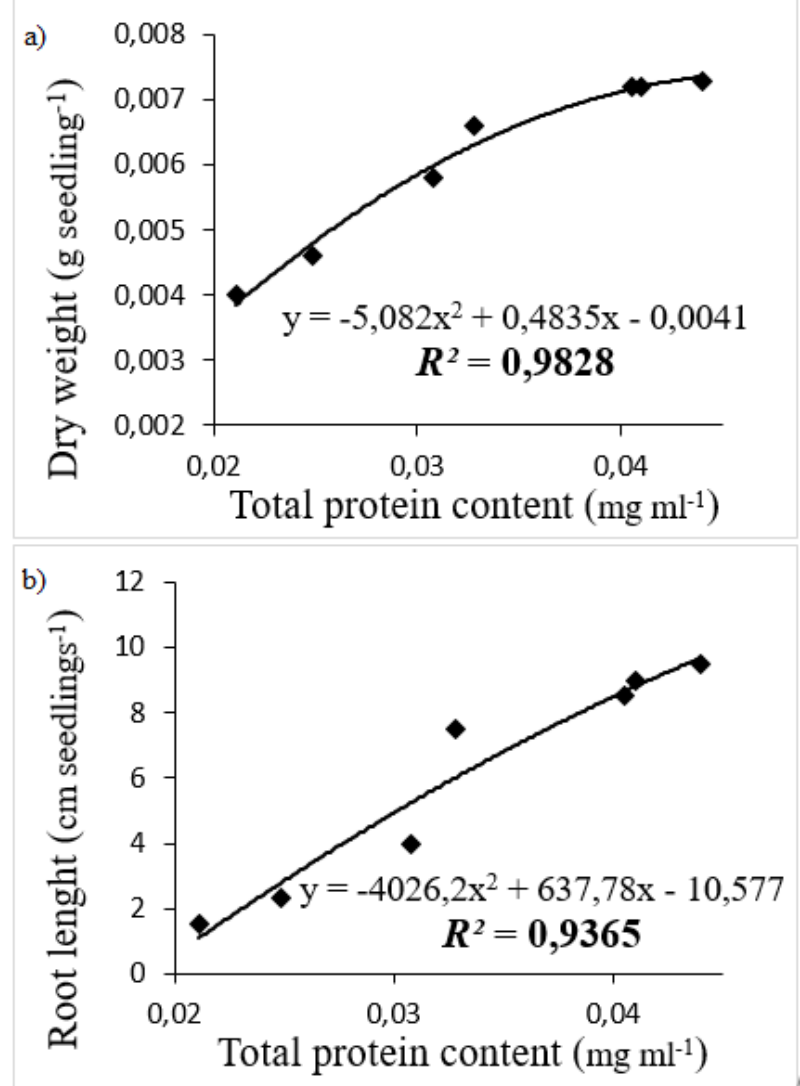

Fig.3: Influence of root total soluble protein contenttoprimaryrootlength (a) anddryweight $(b)$ and $R^{2}$ values

\section{The effect of zinc stress on RAPD profile}

RAPD profile is used to define the genotoxicity in most of the living organisms. There are so many studies about detecting the damage of genotoxic agents on DNA by using RAPD. RAPD methods enable us to examine the relationship between the genotoxic agent and different factors such as concentration and exposure duration. From bacteria to flowery plants, it can be used for so many organisms and it helps to examine multiple samples simultaneously. (Sava, 2000;Atienzaret al.,2002; Liu et al., 2005). For example, Liu et al, (2007); applied 
cadmium $(\mathrm{Cd})$ solution in different concentrations to rice (Oryza sativa L.) seeds and they suggested that the RAPD band patterns have changed in high concentrations. When all the other conditions were kept stable, the only change that took place occurred in the samples with high metal exposure. This situation showed that the genotoxic agent cadmium $(\mathrm{Cd})$ has a mutational effect. According to RAPD analysis, the reason of observing different band profiles in the control is the mutations that occur on the genome sites where the primers are bounded on DNA structure (Liu et al., 2007). Aksoy et al. (2010); also applied copper $(\mathrm{Cu})$ in different concentrations to eggplant seeds. In different copper concentrations, the grown-up seeds can be observed in terms of their genomic structure stability changes by using the RAPD profiles (Aksoyet al., 2010). Cansaran et al. (2011); clearly indicated the genotoxic effect of the air pollution and heavy metal on lichen samples by using RAPD technic. They reported DNA polymorphism induced by accumulation of heavy metal in lichens. They also expressed that RAPD is more sensitive as they give more evidence about DNA damage (Cansaran et al., 2011). In another study, Batir et al. (2016); examined the genotoxic effects of lead and copper treatments with different concentrations on artichoke seedlings. They reported that the lead and copper cause genotoxic effect on the genomes of the artichoke and generate polymorphism in the RAPD band profiles (Batir et al., 2016). In this study, according to the results of RAPD analysis, highly important polymorphism is observed in sunflower samples subjected to zinc stress. 14 of 20 RAPD primers used in this study revealed polymorphic bands that are different from the control group of sunflower. OPC09 (57.2\%), OPC08 (55.5\%), OPC07 (50\%) and OPC11 $(50 \%)$ primers showed considerable polymorphic band patterns. This showed that these primers are powerful indicator for mutagenic effect of heavy metals for sunflower plants. Genomic template stability (GTS, \%) was used to compare the alteration in RAPD profiles with the morphological characters which were root length, dry weight and total protein content in sunflower seedlings. The comparison of GTS (\%), root length, dry weight and total soluble protein content were calculated according to their control value which was set to $100 \%$ (Tables 1). When compared the GTS rates that were obtained from RAPD profiles, the highest rate was $92.85 \%$ at $20 \mathrm{mg} \mathrm{L}^{-}$ ${ }^{1}$ zinc concentration. The lowest rate was $83.33 \%$ at $640 \mathrm{mg} \mathrm{L}^{-1}$ zinc. These results clearly underline the importance of the concentration applied. In addition, it was seen that the genomic template stability significantly affected the primary root length $\left(R^{2}=0.9261\right)$, root dry weight $\left(R^{2}=0.9358\right)$ and root total soluble protein content $\left(R^{2}=0.9216\right)$ (Figure 4).
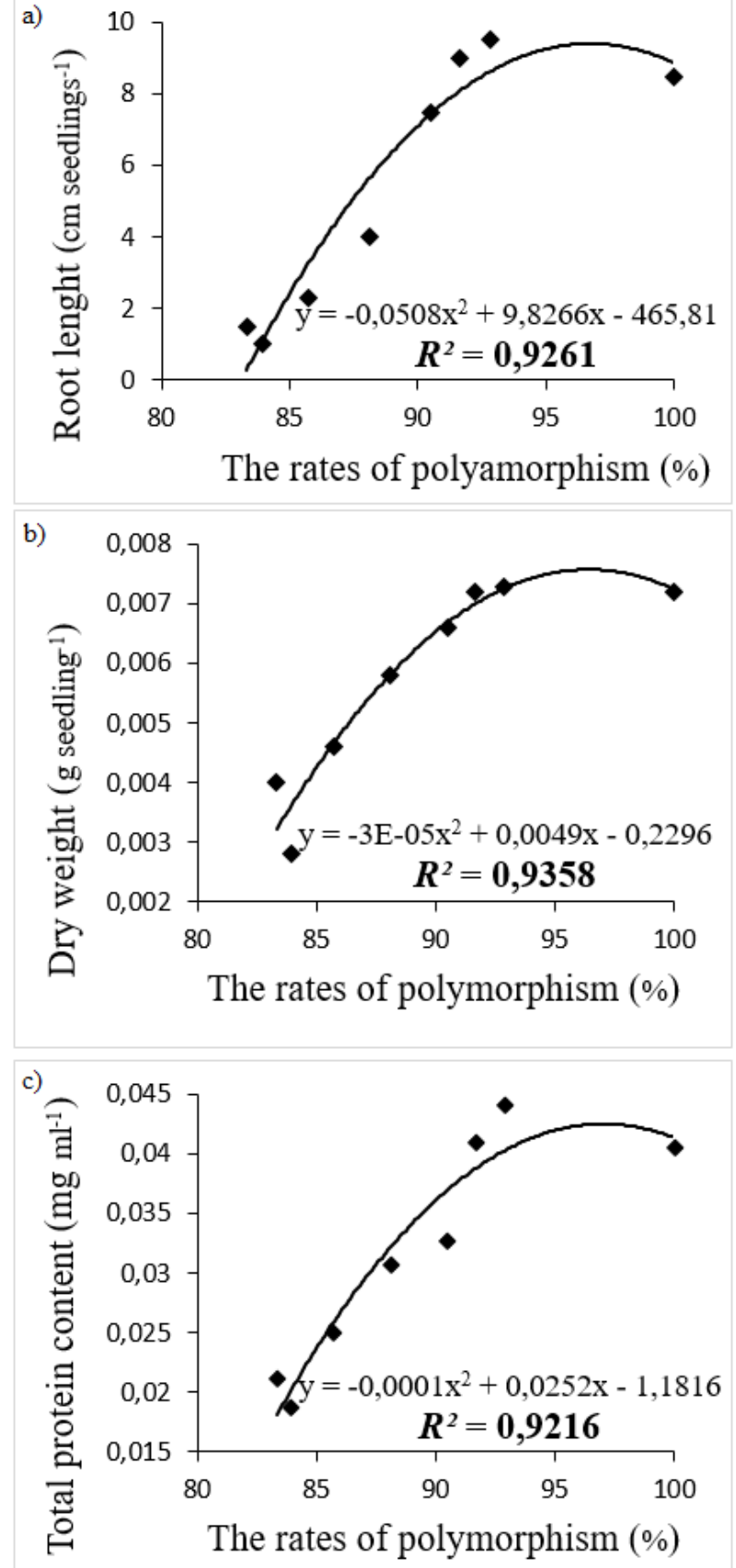

Fig.4: Influence of genomictemplate stability tother oot lenght (a), dryweight of root (b) andsoluble protein content (c) $R^{2}$ values

\section{CONCLUSIONS}

In the current study, serious changes were observed in sunflower plant both in the population level and molecular level when they were exposed to zinc heavy metal. Changes in the level of DNA patterns were seen to be effective on bio-defense mechanism in sunflower plants. Our results indicate that zinc is a genotoxic agent for sunflower plant and it can be useful for restoring zinc contaminated areas with certain levels. Also, with the organism used as the bio-indicator, the biological effects of pollution were detected quantitatively in this study. 


\section{REFERENCES}

[1] Aksoy, D.and Aras, S. 2010.Evaluation of copperstress on eggplant (Solanummelongena L.) seedlings at molecular ve population level susing various biomarkers. MutationResearch.719: 29-34.

[2] Atienzar, F. A., Venier, P., Jha, A. N. and Depledge, M.H. 2002. Evaluation of the random amplified polymorphic DNA (RAPD) assay for the detection of DNA damage and mutations. Mutation Research. 521: 151-163.

[3] Barcelo, J. and Poschenrieder, C. 1990. Plant water relations as effected by heavy metal stres. Journal of PlantNutrition.13: 1-37.

[4] Batir, M. B., Candan, F., Buyuk, I.andAras, S.2015.Thedetermination of physiological and DNA changes in seedlings of maize (Zeamays L.) seed sex posed to the waters of the Gediz River and copper heavy metal stress. Environmental Monitoring and Assessment.187: 169-175.

[5] Batir, M. B., Candan, F.andBuyuk, I. 2015.Determination of the DNA changes in theartichokeseedlings (Cynarascolymus L.) subjected to lead and copperstresses. Plant Soiland Environment. 62(3):143-149.

[6] Bekiaroglu, P.andKarataglis, S. 2002.Theeffect of leadandzinc on Menthaspicata. Journal of AgronomyandCropScience.188: 201-205.

[7] Blackmana, B. K.,Scascitellic, M., Kanec, N. C., Lutona, H. H., Rasmussena, D. A., Byed, R. A., Lentze, D. L.andRieseberga, L. H. 2011.Sunflower domesticationalleles support single domestication center in eastern North America. Proceedings of theNational Academy of Science.108(34): 1436014365 .

[8] Bradford, M. M. 1976. A rapid and sensitive method forth equantitation of microgram quantities of protein utilizingthe principle of protein-dyebinding. Analytical Biochemistry.72: 248-254.

[9] Burzynski, M.and Klobus, G. 2004. Changes of photosynthetic parameters in cucumber leaves under $\mathrm{Cu}, \mathrm{Cd}$ and Pb stress. Photosynth.42(4):505-510

[10] Cansaran,D.,Beyaztas, T., Atakol, O.and Aras, S. 2011.Assesment of the air pollution genotoxicity by RAPD in Everniaprunastri L. Ach. provinceof ironsteelfactory in Karabuk, Turkey. Journal of EnvironmentalSciences.23: 1171-1178.

[11] Hall, J. L. 2002. Cellular mechanisms for heavy metal detoxification and tolerance. Journal of Experimental Botany.53: 1-11.

[12] Kastori, R.,Petrović, M.andPetrović, N. 1992.Effect of excesslead, cadmium, copper, andzinc on waterrelations in sunflower. Journal of PlantNutrition.15: 2427-2439.
[13] Khurana, N.andChatterjee, C.2001.Influence of variablezinc on yield, oilcontent, andphysiology of sunflower. Communications in Soil Science and Plant Analysis. 32: 3023-3030.

[14] Kirbag, F.andMunzuroglu, O. 2006.Toxiceffects of cadmium $(\mathrm{Cd} 2+)$ on metabolism of sunflower (Helianthusannuus L.) seedlings. Acta Agriculturae Scandinavica,Section B-Soil \& PlantScience.3(56): 224-229.

[15] Koc, E., Ustun, A.S.andArici, Y. 2012. Effect of Different Zinc Concentrations on Total Protein, Hydrogen Peroxide Content and Peroxidase Activity in Pepper (Capsicum annuum L.) Seedlings. ArtvinCoruh University, Journal of Forestry Faculty.13(2): 205-212.

[16]Lefort, F., Lally, M., Thompson, D.and Douglas, G. 1998. Morphological traits, microsatellite fingerprinting and genetic relatedness of a stand of elite oaks ( $Q$. robur L.) at Tullynally, Ireland, Silvae.Genetica.47: 257-261.

[17]Lentz, D. L., Pohl, M. D., Alvarado, J. L., Tarighat, S.and Bye, R. 2008. Sunflower (Helianthus annuus L.) as a pre-Columbian domesticate in Mexico. Proceedings of the National Academy of Science.105: 6232-6237.

[18]Levitt, J. (1972).Responses of plantstoenvironmentalStresses. New York, London: AcademicPress. 697.

[19]Liu, W., Li, P., Qi, X., Zhou, Q., Zheng, L., Sun, T.and Yang, Y. 2005. DNA changes in barley Hordeum vulgare seedlings induced by cadmium pollution using RAPD analysis.Chemosphere.61: 158-167.

[20]Liu, W., Yang, Y. S., Zhou, Q. X., Xie, L. J., Le, P. J.and Sun, T. H. 2007. Impact assessment of cadmium contamination on rice (Oryza sativa L.) seedlings at molecular and population levels using multiple biomarkers. Chemosphere. 67: 1155-1163.

[21] Savva, D.2000. The use of arbitrarily primed PCR (AP-PCR) fingerprinting to detect exposure to genotoxic chemicals. Ecotoxicology. 9: 341-353.

[22] Soydam, A. S.,Gokce, E., Buyuk, I.and Aras, S. 2012. Characterization of stress induced by copper and zinc on cucumber (Cucumissativus L.) seedlingsbymeans of molecular and population parameters. Mutation Research.746: 49-55.

[23] Steinkellner, H., Mun-Sik, K., Helma, C., Ecker, S., Ma, T. H., Kundi, M. and Knasmuller, S. 1998.Genotoxic effects of heavymetals: comparative investigation with plant bioassays. Environmental and Molecular Mutagenesis. 31: 183-191.

[24] Yarsan, E., Bilgili, A.andTurel, I. 2000.Heavy metal levels in mussels (UniostevenianusKrynicki) 
obtainedfrom Van Lake. TurkishJournal of Veterinary\&AnimalSciences.24: 93-96.

[25]Zengin, F. K.andMunzuroglu, O. 2004.Effect of lead $\left(\mathrm{Pb}^{2+}\right)$ andcopper $\left(\mathrm{Cu}^{2+}\right)$ on thegrowth of root, shootandleaf of bean (Phaseolusvulgaris L.) seedlings. Gazi UniversityJournal of Science.173: 110. 